\title{
Long non-coding RNA HAGLR inhibits growth and metastasis and reduces stemness of lung cancer cells through the microRNA-330-3p/SLC34A2 axis
}

\section{Chunxia Yang}

Liuzhou Traditional Chinese Medical Hospital

\section{Dukai Chen}

People's Hospital of Lin'an District

\section{Xiaoling Zhong}

the Ninth Affiliated Hospital of Guangxi Medical University

Fangding Yang ( $\nabla$ fangdingyang120501@163.com )

People's Hospital of Lin'an District https://orcid.org/0000-0003-1722-1953

Research article

Keywords: Lung cancer, Long non-coding RNA HAGLR, Competing endogenous RNA, microRNA-330-3p, slc34a2, Wnt/ $\beta$-catenin signaling pathway, Stemness

Posted Date: August 7th, 2020

DOI: https://doi.org/10.21203/rs.2.22646/v2

License: (c) (i) This work is licensed under a Creative Commons Attribution 4.0 International License. Read Full License 
The authors have withdrawn this preprint from Research Square 